\title{
Xylogenesis in the early life stages of maritime pine
}

\author{
Joana Vieira*, Ana Carvalho, Filipe Campelo \\ CFE - Centre for Functional Ecology - Science for People \& the Planet, Department of Life Sciences, University of Coimbra, Calçada Martim de Freitas, 3000-456 Coimbra, \\ Portugal
}

\begin{abstract}
A B S T R A C T
Trees change throughout their life stages, and although age-dependent changes are reported in the literature, the early life stages of trees are often excluded from these studies. The sapling/pole life stage corresponds to the establishment phase of a tree in the forest. To understand how wood formation changes in the early growing stages we compared xylogenesis in saplings/pole (10-15 years old) and young trees (50-55 years old). Trees were selected from two adjacent areas in different regeneration phases from a maritime pine (Pinus pinaster Aiton) plantation located on the west coast of Portugal. The cambial and differentiating xylem cells were monitored from March 2015 to March 2017. The climatic conditions in these years were contrasting: 2015 was hot and dry and 2016 wet. Xylogenesis started around the same time in both age-classes but ended later in young trees in both years. Despite the shorter duration, sapling/pole trees formed more tracheids than young trees in both years, presenting an intensive growth strategy. Tracheids in young trees did not present differences between years, but sapling/pole trees presented fewer tracheids with a higher latewood proportion and smaller lumen area in the driest year (2015). Our results show that sapling/pole trees have an intensive growth strategy, whereas older trees (50-55 years) present a conservative growth strategy with a longer growing season. If the frequency and intensity of droughts increases, sapling/pole trees will reduce growth immediately, whereas older trees will reduce productivity in the following years. Thus, it is expected that forest productivity will decrease under a scenario of increasing drought.
\end{abstract}

\section{Introduction}

Trees are the dominant element in a forest. During their lifetime, trees process and store large quantities of carbon. As trees get older and taller physiological processes such as photosynthetic capacity, hydraulic conductivity and growth rate change (Martínez-Vilalta et al., 2007; McDowell et al., 2005). Changes in growth rate affect net carbon uptake and losses, which can have serious consequences for the global carbon cycle, since carbon is stored in trees during wood formation (Cuny et al., 2015). Wood formation or xylogenesis is a genetically controlled process dependent on the ontogenetic status of trees (Begum et al., 2013). Studies comparing xylogenesis between age groups have reported that the duration of xylogenesis was shorter on old trees (Rossi et al., 2008) and that young trees presented faster growth rates (Li et al., 2013). In both studies, the trees designated as young were older than 40 years. Thus, although the age-dependence of wood formation has been addressed in the literature, no study has investigated it in sapling/pole trees. During their lifetime, trees go through different phases: seedling, saplings, pole, young/mature and old trees. The sapling phase is characterized by individuals that have not yet reach sexual maturity and the pole phase by trees that although sexually mature, have not yet reached the full height for the species (Santos-del-Blanco et al., 2012).

It is well known that trees present a biological growth trend, by which trees form wider tree rings during their early years (Ivković et al., 2013). This biological growth trend is commonly removed by dendrochronological standardization. By doing so, the climate response is considered to be age-independent. However, several dendrochronological studies have shown that tree growth responses to climate are site-, age- and species-dependent (Campelo et al., 2018; Carrer and Urbinati, 2004; Szeicz and MacDonald, 1994; Vieira et al., 2009; Wang et al., 2009; Yu et al., 2008). For instance, it was found that young trees (65-75 years old) of Pinus pinaster Aiton started to grow earlier and thus responded to climatic conditions earlier in the growing season, whereas old trees (115-200 years old) presented a stronger climatic signal (Vieira et al., 2009). The xylogenesis of this species has also been studied in young trees (50-60 years) (Vieira et al., 2014a, 2014b), however xylogenesis has not yet been compared among different life stages. Studies reporting on the cambial activity and wood formation dynamics of maritime pine trees have observed that warmer

\footnotetext{
* Corresponding author.

E-mail address: joana.vieira@uc.pt (J. Vieira).
} 
winters triggered an earlier onset of xylogenesis and that xylogenesis duration was dependent on water availability, stopping earlier in drier years (Vieira et al., 2015, 2014a). Although some studies have investigated the climatic response of xylogenesis in maritime pine, none of them have considered the most vulnerable life stage, the sapling/pole phase.

The age-dependent climatic response of trees presents an additional challenge: estimating the growth of trees and forests growth under the forecast climate change. Climate change is one of the greatest environmental challenges for mankind in the twenty-first century (Beniston et al., 2007). Temperatures are rising and the precipitation regime has become more irregular with extreme events such as dry spells and floods becoming more frequent (Coumou and Rahmstorf, 2012). The climatic scenarios for the Mediterranean region project a higher risk of summer drought associated with decreasing precipitation and increased temperature (Christensen et al., 2007). Understand how sapling/pole trees will respond to such conditions is critical to predict forest succession and tree establishment and productivity in the future. The two years reported in this study represent a very dry year (2015) and a wet year (2016). Comparing the response of xylogenesis in young and sapling/pole trees in two contrasting years will determine how this response is modulated by age and climate, shedding some light on the future response of maritime pine forests.

In the present study we compared the cambial activity and xylogenesis in saplings/pole ( $13 \pm 2$ years) and young (52 \pm 2 years) maritime pine trees (Pinus pinaster Aiton) growing in the west coast of Portugal. The aim of this study is to determine (1) if cambial activity and wood formation are age-dependent; (2) if there are differences in the timings of xylogenesis between age-classes and (3) if the rates of cell production change with age. We determined that sapling/pole trees presented a higher rate of cell production than young trees. Regarding the climatic impact on wood formation, although young trees showed no differences in tracheid production between years, sapling/pole tress formed fewer tracheids in the drier year. Our results are relevant for forest management strategies as they report how trees in the early life stages respond to climate.

\section{Materials and methods}

\subsection{Study site and tree selection}

The study was performed in a permanent plot, located in Perímetro Florestal Dunas de Cantanhede, in the west coast of Portugal $\left(40^{\circ} 21^{\prime} 35.15^{\prime \prime} \mathrm{N}, 8^{\circ} 49^{\prime} 10.06^{\prime \prime} \mathrm{W} ; 15 \mathrm{~m}\right.$ a.s.l.). The plot is a maritime pine (Pinus pinaster Aiton) plantation on sand dunes. For this study we selected trees located in two adjacent stands, in different regeneration phases: one with sapling/pole trees and another with young trees. Sapling/pole trees were $13 \pm 2$ years-old and young trees $52 \pm 2$. Tree age was determined by removing a core from each tree at breast height. Sapling/pole (young) trees presented a diameter at breast height $(\mathrm{DBH})$ of $11.8 \pm 1.4(34.4 \pm 5) \quad \mathrm{cm}$ and $5.4 \pm 0.5$ $(15.2 \pm 0.8) \mathrm{m}$ of height.

The climate is typically Mediterranean with precipitation occurring mainly in the fall and winter months and the summer is dry and warm. The mean annual temperature for the last 30 years $(1985$ - 2014) was $16.3^{\circ} \mathrm{C}$, and the average total annual precipitation of $877 \mathrm{~mm}$. Daily values of maximum and minimum temperature and precipitation were downloaded from the Royal Netherlands Meteorological Institute (http://www.climexp.knmi.nl/; v15.0).

A soil moisture probe PR2 from Delta-T-Devices was installed in the study site (in January 2014) and programed to record soil moisture values every $30 \mathrm{~min}$ at a depth of $100 \mathrm{~cm}$. Data were stored in a DL2e data logger also from Delta-T-Devices.

\subsection{Cambial activity and wood formation}

Sampling was performed on five trees per age-group from March $9^{\text {th }}$ 2015 to March $15^{\text {th }} 2017$ by collecting microcores from the tree stem using a Trephor (Rossi et al., 2006). Samples were taken every 10 days from $45 \mathrm{~cm}$ above and below breast height, on the south-facing side of the stem, in order to minimize growth variability around the stem (Lupi et al., 2014). Each sample was collected at approximately $5 \mathrm{~cm}$ from each other to prevent getting resin ducts formed in response to the previous samplings. Before collecting the microcore, the dead bark was carefully removed to reach the living tissues. Wood microcores were placed in eppendorfs filled with alcohol $50 \%(\mathrm{v} / \mathrm{v})$ and stored in the refrigerator $\left(5{ }^{\circ} \mathrm{C}\right)$ to prevent tissue deterioration. The samples were then processed by successive immersions in alcohol and D-limonene solutions of increasing concentration until dehydrated, and then embedded in paraffin. Transverse sections $7 \mu \mathrm{m}$ thick were cut from the samples with a rotary microtome, stained with cresyl violet acetate $(0.17 \%)$, and immediately observed with a microscope (Leica, DM4000B) under visible and polarized light to distinguish between the xylem cells in different stages of development. Cambial and enlarging cells only present primary wall, thus do not shine under polarized light. Cambial cells are characterized by a small radial diameter while enlarging cells present a diameter of at least twice that of a cambial cell. Wall thickening cells shine under polarized light and present a violet coloration changing to dark violet at the end of maturation. Mature cells present a blue coloration in the entire cell wall. In each sample, the number of cambial, enlarging, wall thickening and mature xylem cells were counted along three radial rows.

The total number of cambial, enlarging, cell-wall thickening and mature cells determined during the growing season were fitted with generalized additive models (GAMs) in order to compare the effect of early growth stage in xylogenesis using the $m g c v$ package (Wood, 2006) in the R computing environment (R Development Core Team, 2016). For each year, differences between sapling/pole and young trees were considered significant when the point-wise confidence intervals of the fitted curves did not overlap.

A linear regression was calculated between the duration of xylogenesis and the number of tracheids formed in each year per group of trees.

\subsection{Xylem phenology}

The number of cells in each differentiation phase at each sampling point was used to assess the onset and end of the xylem differentiation phases. The onset of each phase was considered when at least one cell was observed per row. At the end of the growing season, the end of each differentiation phase was considered when no cells were observed in that phase. Xylem phenology was represented by the dates corresponding to: the first enlarging tracheid; the first cell wall thickening tracheid; the first mature tracheid; the last enlarging tracheid and the last wall thickening tracheid. The timings of xylogenesis were computed as day of year (DOY) and determined for each tree and year. The computation of the critical dates was performed using the $\mathrm{R}$ package CaviaR (Rathgeber et al., 2011).

The dynamics of tracheid production were assessed by fitting a Gompertz sigmoid curve to the total number of tracheids produced over the growing season (Rossi et al., 2003), defined as:

$y=a \times e^{-e^{(b-k \times t)}}$

where $y$ is the cumulative number of tracheids; $t$ is time; $a$ is the upper asymptote corresponding to the maximum number of tracheids produced; $b$ the $\mathrm{x}$-axis placement parameter; and $k$ is the growth rate parameter that determines the spread of the curve along the $\mathrm{x}$-axis.

Gompertz functions were fitted for each group of trees and their parameters used to calculate the dates at which $5 \%$ and $95 \%$ of the cells 
were produced $\left(t_{5}\right.$ and $\left.t_{95}\right)$; the date of inflexion point $\left(t_{i p}\right)$; the maximal growth rate $\left(r_{\max }\right)$; the average growth rate $\left(r_{90}\right)$ and duration $\left(\mathrm{Dt}_{90}\right)$, for the period when $90 \%$ of the tracheids were produced. All parameters were calculated using the $\mathrm{R}$ package CaviaR (Rathgeber et al., 2011).

\subsection{Tracheid anatomy}

In March 2017 an extra microcore was collected from each tree and processed as described above to compare tracheid features between age-classes and years. The sections obtained were stained with $1 \%$ aqueous safranin and permanently mounted on glass slides with Eukitt. Tree rings produced in 2015 and 2016 were photographed using a camera fixed on a microscope (Leica, model DCF295), at $20 \times$ magnification. Three radial rows were selected in each image to measure the radial lumen diameter and cell wall thickness of each tracheid. Images were analyzed using the freely available ImageJ program (https://imagej.nih.gov/ij/). Tracheids were classified in earlywood and latewood according to the Mork's formula described in Denne (1989). Earlywood and latewood tracheid features were compared between groups of trees and years using generalized linear mixed models (GLMMs), with early growth stage and time as fixed factors and tree identity as random factor. The analysis was computed in $\mathrm{R}$ using the function lme from the nlme package (Pinheiro et al., 2016), which uses the restricted maximum likelihood methodology (REML). Relationships were considered significant when $P<0.05$.

\section{Results}

\subsection{Weather in 2015 and 2016}

The two study years presented different climatic conditions (Fig. 1). The year 2015 was warmer and drier than 2016. The mean annual temperature in 2015 was $16.01{ }^{\circ} \mathrm{C}$ and the annual precipitation was $625 \mathrm{~mm}$, whereas in 2016 the mean annual temperature was $15.78{ }^{\circ} \mathrm{C}$ and the annual precipitation was $1250 \mathrm{~mm}$, double of the amount measured in 2015. Precipitation in 2015 was below the long-term average for the last 30 years $(877 \mathrm{~mm})$. Regarding the seasonal distribution of precipitation there were also differences between years (Fig. 1). In 2015 the winter and spring were drier than in 2016 (265 vs. $947 \mathrm{~mm})$.

Mean temperatures in winter were 9.97 and $11.32{ }^{\circ} \mathrm{C}$ in 2015 and 2016 (Fig. 1). The spring of 2015 was warmer, with a mean

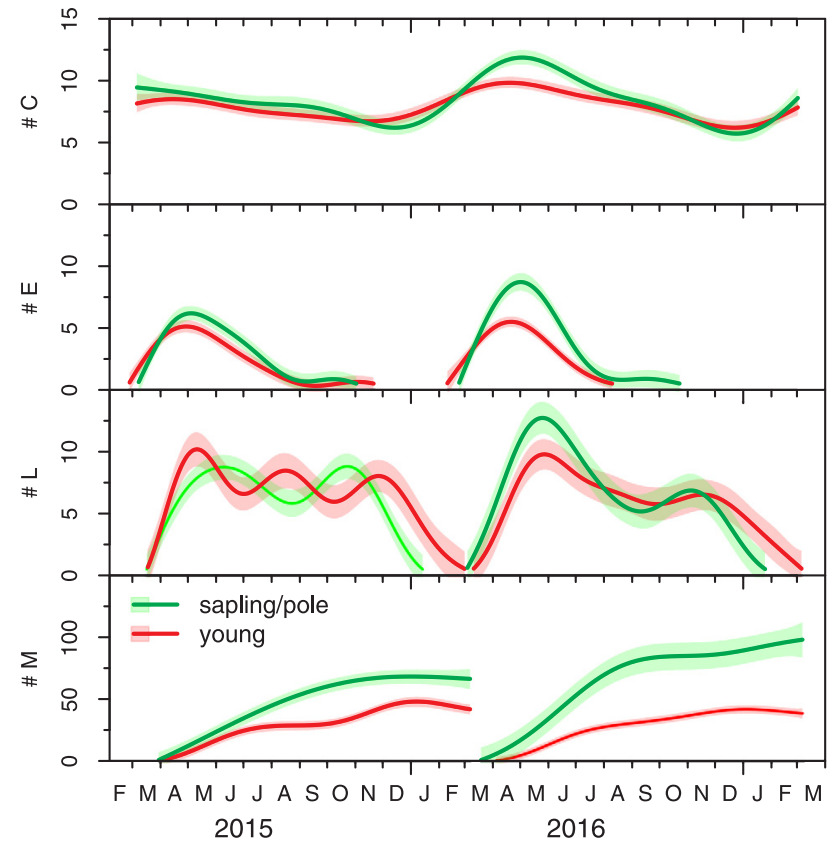

Fig. 2. Generalized additive models (GAMs) fitted to the number of cambial (\# C), enlargement (\# E), cell wall thickening (\# L) and mature cells (\# M). Lines are the fitted curves and the shaded areas the $95 \%$ confidence interval. Sapling/ pole trees are represented in green and young trees in red. The difference between sapling/pole and young trees is considered significant when confidence intervals do not overlapped. (For interpretation of the references to colour in this figure legend, the reader is referred to the web version of this article.)

temperature of $17.42{ }^{\circ} \mathrm{C}$ versus the $15.50{ }^{\circ} \mathrm{C}$ registered in 2016 . The mean summer temperature was $1{ }^{\circ} \mathrm{C}$ warmer in 2016 than in 2015 (21.6 and $20.6{ }^{\circ} \mathrm{C}$, respectively). Mean fall temperatures where similar between years: 15.58 in 2015 and $14.95^{\circ} \mathrm{C}$ in 2016 .

The field-measurements of soil water content (SWC) reflected the differences in precipitation observed between years (Fig. 1). In 2015, SWC was higher during winter but started to decrease in March, whereas in 2016 SWC increased from January to mid-May, and only then it started to decrease reaching a minimum in September. In 2015 SWC recovered in June, corresponding to a period of precipitation, however it was still lower than in the same period of 2016. By the end of June SWC started to decrease again, reaching the lowest value in

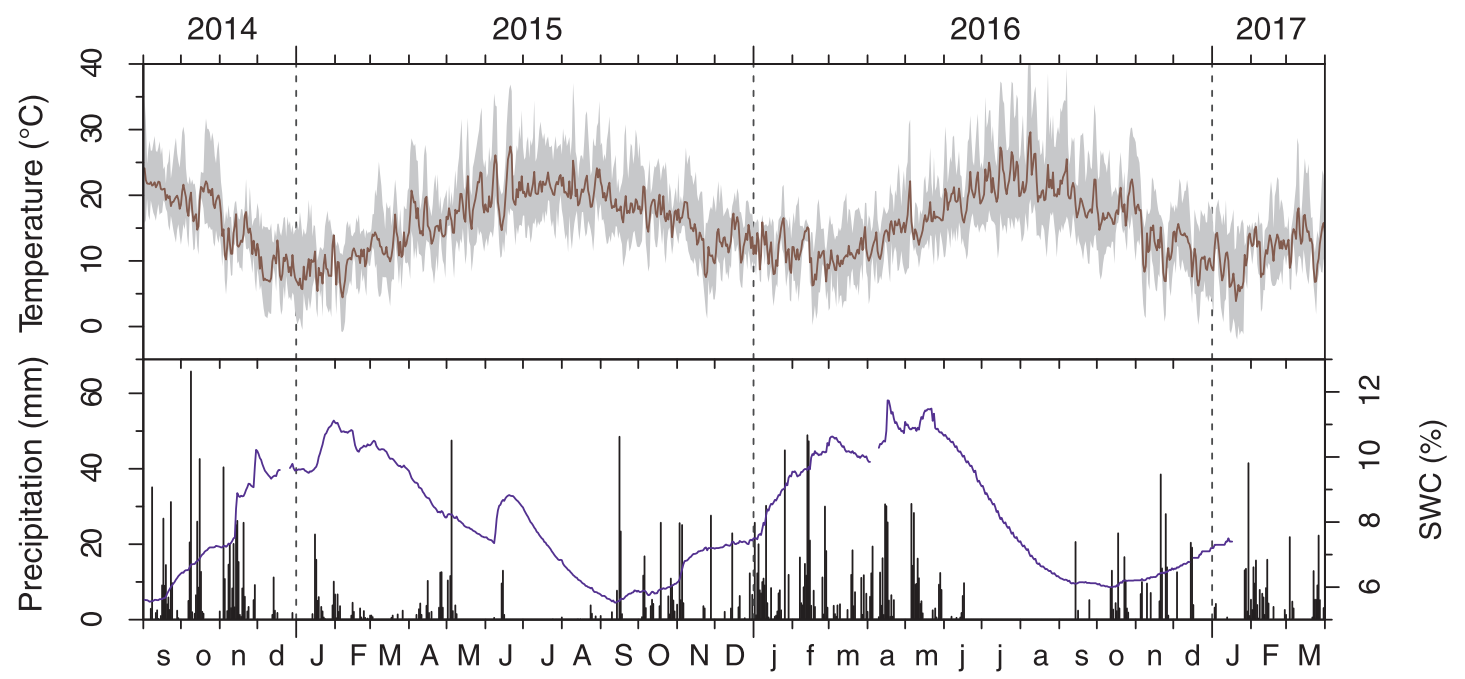

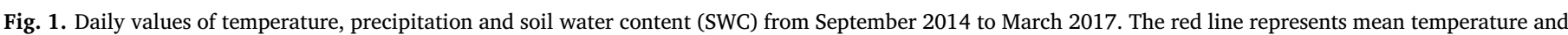

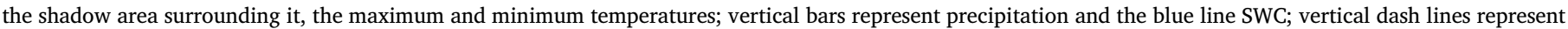
the transition between years. 
September. In 2015 SWC started to recover in mid-September, whereas in 2016 this recovery was only observed in November (Fig. 1).

\subsection{Seasonal dynamics of xylem phenology}

The seasonal variation in the number of cambial and xylem differentiating cells presented differences between groups of trees and years (Fig. 2). Cambial activity started before the first sampling in March 2015. Regarding the seasonal variation in the number of cambial cells in 2015, it was similar between groups of trees. The maximum number of cambial cells was observed in spring (ca. 9-11 cells), slowly decreasing afterwards until December-January, when a minimum of 6 cells was observed in sapling/pole trees and 7 cells in young trees. In 2016 cambial activity started in February in both groups of trees. The seasonal variation in the number of cambial cells was similar between groups, although a higher number of cells were present in sapling/pole trees from mid-March to July. In this period sapling/pole trees presented ca. 11 cambial cells, whereas young trees presented approximately 9. After July the number of cambial cells decreased, reaching a minimum of ca. 6 cells in December. The 2017 cambial re-activation was observed in the end of February in both groups of trees.

Enlarging xylem cells started to be observed in mid-March in both groups and study years (Fig. 2). In 2015, both groups of trees presented a similar variation in the number of enlarging cells, with a maximum of 6 cells observed in April-May. In 2016, however, sapling/pole trees presented more enlarging cells than young trees from March to May. In sapling/pole trees there were on average 9 cells, whereas in young trees there were 6 . The first lignifying cells were observed in the beginning of March in both years and group of trees. The number of lignifying cells was similar between groups in 2015, but in 2016 a higher number of lignifying cells was observed in sapling/pole trees from March to July. In both years, the lignification period was shorter in sapling/pole trees. Mature cells were first observed in sapling/pole trees in the beginning of April and two weeks later in young trees, in both years. In 2015 (2016), a total of 70 (90) tracheids were produced in sapling/pole trees, whereas young trees produced 45 tracheids in both study years.

The onset, end and duration of each xylem differentiation phase presented differences between groups of trees and years (Fig. 3, Table S1). The onset of xylem differentiation (enlargement) was simultaneous between groups but not between years, starting earlier in 2016. In sapling/pole trees enlargement ended later in 2015 thus presenting a longer duration (Fig. 3, Table S1). Cell wall deposition started simultaneously in both groups of trees and years but it ended earlier in
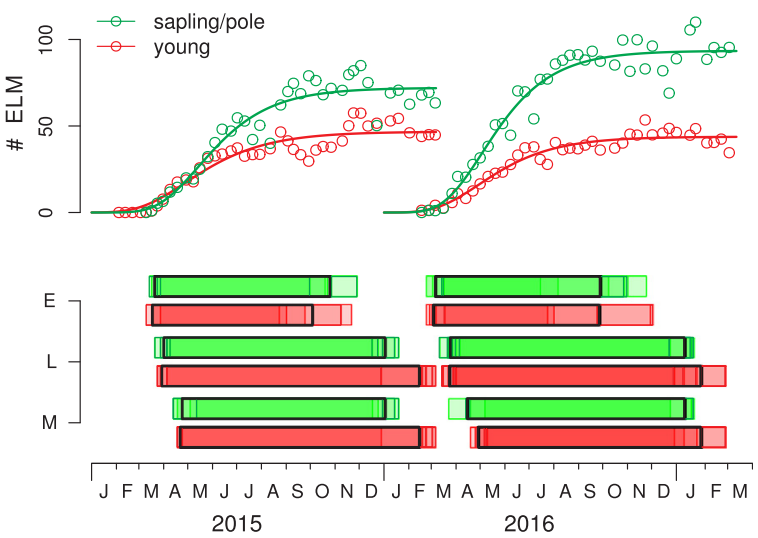

Fig. 3. Total number of tracheids present at each sampling date (ELM) and phenological timings for each xylem differentiation phase in sapling/pole (green bars) and young trees (red lines), in the 2015 and 2016 growing seasons; the coefficients of the Gompertz functions are presented in Table 2. The black rectangle indicates the mean phenological timings for the enlargement (E), lignification (L) and mature (M) phases.

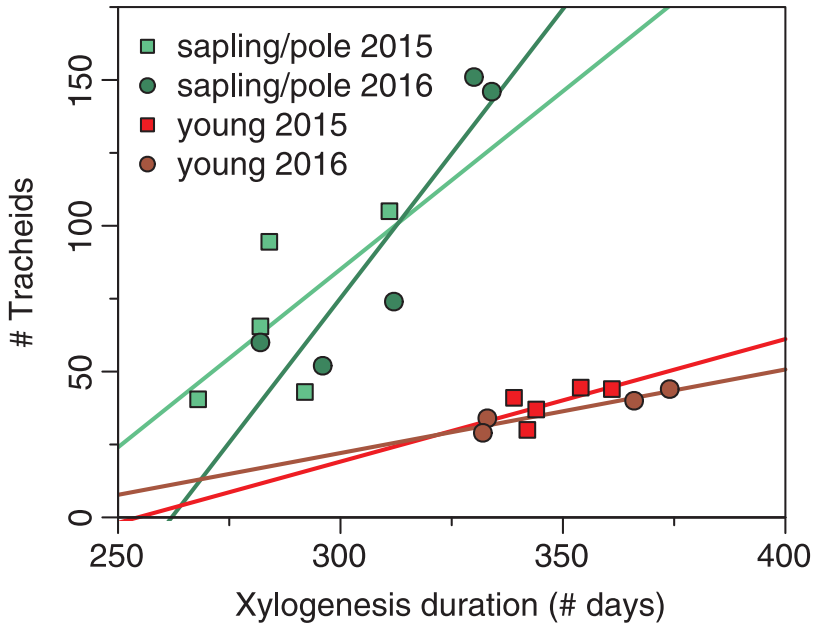

Fig. 4. Linear regression between duration of xylogenesis and the number of tracheids formed in sapling/pole (green) and young (red) in 2015 (squares) and 2016 (circles). (For interpretation of the references to colour in this figure legend, thereader is referred to the web version of this article.)

sapling/pole trees, thus sapling/pole trees presented a shorter lignification phase. Although the first mature tracheids were observed at approximately the same time in both groups of trees and years, xylogenesis was ca. 40 days longer in young trees in both years (Fig. 3, Table S1). When plotting the number of tracheids produced versus the duration of xylogenesis, it is possible to observe that sapling/pole trees formed more tracheids in a shorter period (Fig. 4).

The increase in the number of tracheids through time could be represented by a sigmoid "s-shape" curve (Fig. 3). Thus, a Gompertz function was fitted to the total number of tracheids in the various differentiation phases (enlargement, wall thickening and mature cells) to model tree growth (Fig. 3; Table 1). The maximum $\left(r_{\max }\right)$ and average rate of cell production $\left(\mathrm{r}_{90}\right)$ were higher in sapling/pole trees in both study years. The most significant differences in cell production were observed in 2016, with sapling/pole trees presenting a maximum of 0.71 cells/day, whereas young trees presented 0.31 (Table 1 ).

\subsection{Tracheids}

The number, lumen diameter and cell wall thickness were compared in earlywood and latewood tracheids in both groups of trees and study years (Fig. 5, Table 2). Sapling/pole trees formed more earlywood tracheids in 2016 than in 2015, and in both years, more than young trees. Young trees formed a similar number of earlywood tracheids in

Table 1

Parameters of the Gompertz funtions for Pinus pinaster sapling/pole and young trees. ( $a$, upper asymptote; $b$, x-axis placement parameter; $k$, growth rate parameter that determines the spread of the curve along the $\mathrm{x}$-axis; $t_{5}$ and $t_{95}$, dates at which 5 and $95 \%$ of the cells are produced; $t_{t i p}$, date of the inflexion point; $D t_{90}$, days needed to produce $90 \%$ of the total number of cells; $r_{\max }$, maximal rate of cell production; $r_{90}$, average rate of cell production).

\begin{tabular}{lllll}
\hline & 2015 & & 2016 & \\
\cline { 2 - 5 } & Sapling/Pole & Young & Sapling/Pole & Young \\
\hline $\mathrm{a}$ & 72.1 & 46.7 & 93.5 & 43.8 \\
$\mathrm{~b}$ & 2.652 & 2.060 & 2.536 & 2.245 \\
$\mathrm{k}$ & 0.020 & 0.018 & 0.021 & 0.019 \\
$\mathrm{t}_{5}$ & 78 & 55 & 70 & 61 \\
$\mathrm{t}_{\text {tip }}$ & 133 & 117 & 123 & 118 \\
$\mathrm{t}_{95}$ & 283 & 286 & 266 & 275 \\
$\mathrm{Dt}_{90}=\mathrm{t}_{95}-\mathrm{t}_{5}$ & 205 & 231 & 197 & 215 \\
$\mathrm{r}_{\max }$ & 0.53 & 0.30 & 0.71 & 0.31 \\
$\mathrm{r}_{90}$ & 0.32 & 0.18 & 0.43 & 0.18 \\
\hline
\end{tabular}




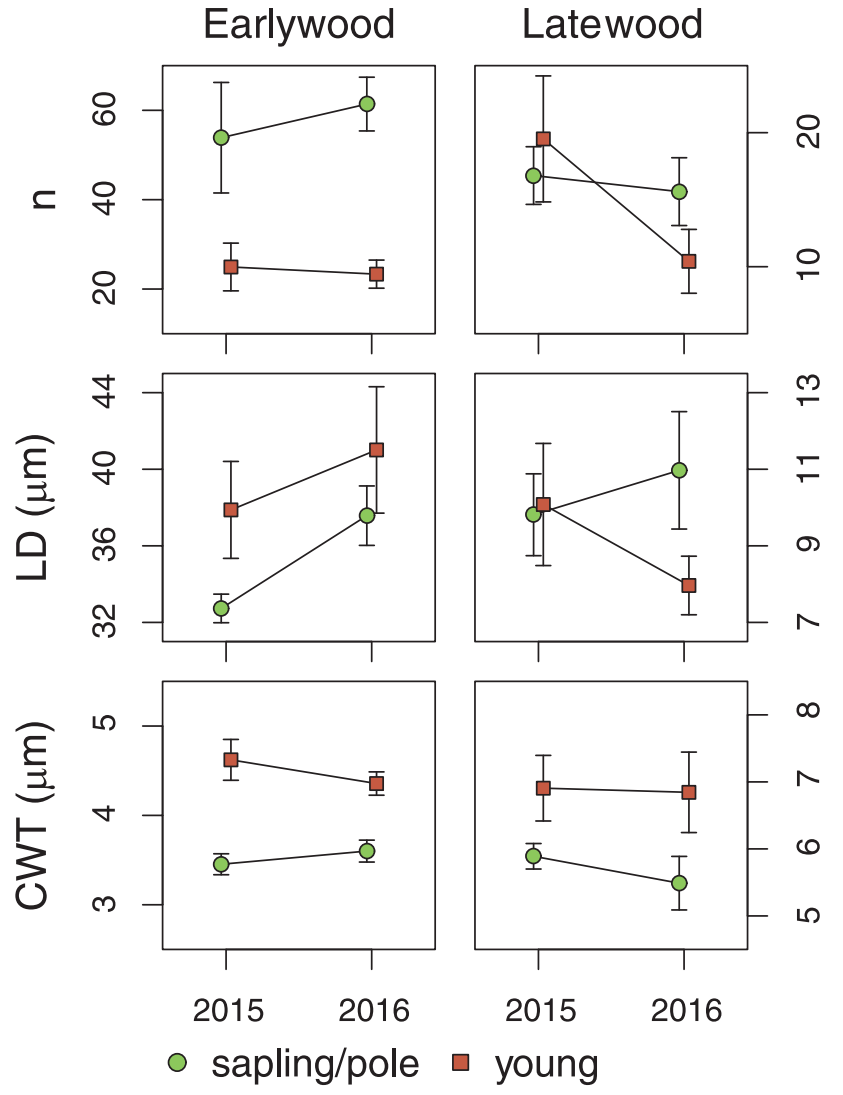

Fig. 5. Number (n), lumen diameter (LD) and cell wall thickness (CWT) of earlywood and latewood tracheids from sapling/pole (green circles) and young trees (red squares) in 2015 and 2016. Tests for differences are presented in Table 2. (For interpretation of the references to colour in this figure legend, the reader is referred to the web version of this article.)

both years. Regarding the number of latewood tracheids, there were differences between years, with a higher number of latewood tracheids present in 2015, but no significant differences between tree groups were observed. The lumen diameter of sapling/pole trees earlywood tracheids in 2015 was smaller than in 2016, and also smaller than the lumen of young trees earlywood tracheids. In 2016 there were no differences in the earlywood lumen of sapling/pole and young trees. In latewood, the lumen diameter did not differ neither between tree groups nor years. Regarding cell wall thickness, it was thicker in young trees tracheids, both in earlywood and latewood, and in both years.

\section{Discussion}

This study investigated the timings and rates of xylem cell production in the early growing stages of maritime pine trees: sapling/pole and young trees. The study site was located on the west coast of Portugal, under a Mediterranean climate with oceanic influence. The study was carried out over two years with contrasting weather conditions: 2015 was hot and dry, and 2016 wet. There were differences in the timings and rates of xylem formation between years and groups of trees. Sapling/pole trees presented a higher rate of cell production and although the period of xylem differentiation was longer on young trees, they formed fewer tracheids in both years.

\subsection{Timings of cambial activity and limitations to tree growth}

There is some speculation on whether or not there is an actual stop of cambial activity during winter in evergreen trees growing under Mediterranean climate (Cherubini et al., 2003; Vieira et al., 2015). Here we observed a clear stop of cambial activity from mid-December to midFebruary, characterized by a reduction in the number of cambial cells and by the absence of enlarging cells. Cambial activity is known to be controlled by intrinsic factors such as age, size and genetics and by external factors such as temperature and photoperiod (Begum et al., 2013). Previous studies on the xylogenesis of maritime pine growing under Mediterranean climate showed that cambial onset is limited by temperature, starting to divide earlier in years following warmer winters (Vieira et al., 2015, 2014a). Although we missed the onset of cambial activity in 2015, we observed it in the next two years. The resumption of cambial activity was observed in early February in 2016 and in late February in 2017. The winter of 2016 was $1{ }^{\circ} \mathrm{C}$ warmer than the winter of 2017, confirming previous studies stating that cambial onset in maritime pine growing under Mediterranean climate is limited by temperature, starting to divide earlier in years following warmer winters (Vieira et al., 2015, 2014a). These studies suggest that there is a temperature threshold for cambial resumption in the Mediterranean region however a long-term and widely-distributed study is still necessary to establish this threshold.

\subsection{Tracheid production}

Although no differences were observed in the onset of cambial activity between groups of trees, sapling/pole trees formed more tracheids than young trees in both years. Differences in cell production can be explained by the duration of xylogenesis or by the rates of cell production (Cuny et al., 2015; Lupi et al., 2010; Rossi et al., 2014). Here, those differences could not be explained by the duration of xylogenesis since it lasted longer on young trees in both years (Fig. 4). Thus, it must be the rate of cell production. In fact, sapling/pole trees had a higher number of enlarging cells than young trees during most of the growing season. This difference was even higher in 2016, when sapling/pole trees formed more than double the number of tracheids observed in young trees. Previous studies in maritime pine in this region have also related higher rates of cell production to higher rates of cell division (Vieira et al., 2015, 2014b), in contrast to what was found in Boreal sites where higher rates of cell production were related to xylogenesis duration (Lupi et al., 2010; Rossi et al., 2014).

Regarding the differences in xylogenesis duration, it lasted longer on young trees, although this difference was not reflected in the final number of tracheids. From the literature it was expected that sapling/

Table 2

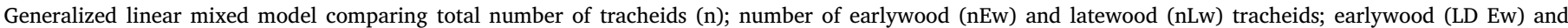

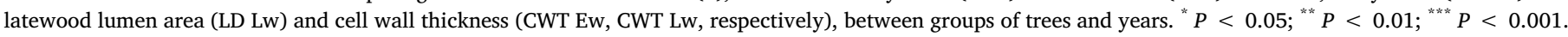

\begin{tabular}{|c|c|c|c|c|c|c|c|}
\hline & $\mathrm{n}$ & nEw & nLw & LD Ew & LD Lw & CWT Ew & CWT Lw \\
\hline Intercept & $70.67 \pm 9.44^{* 2 k+k}$ & $53.87 \pm 7.54^{\text {whkt }}$ & $16.80 \pm 3.11^{* k * k}$ & $32.73 \pm 2.25^{k \text { k* }}$ & $9.81 \pm 1.29^{* k * k}$ & $3.45 \pm 0.16^{\text {*.*k }}$ & $5.89 \pm 0.45^{* * * * x}$ \\
\hline Year & $6.33 \pm 8.63$ & $7.53 \pm 6.58$ & $1.20 \pm 3.35$ & $4.85 \pm 2.48$ & $1.16 \pm 1.02$ & $0.15 \pm 0.14$ & $-0.40 \pm 0.14$ \\
\hline Group & $-26.2 \pm 13.35^{*}$ & $-28.93 \pm 10.67^{\text {w*t }}$ & $2.73 \pm 4.40$ & $5.15 \pm 3.18$ & $0.27 \pm 1.82$ & $1.17 \pm 0.22^{*}$ & $1.02 \pm 0.63$ \\
\hline $\begin{array}{l}\text { Year } \times \text { Group } \\
\text { Random effect }\end{array}$ & $-17.07 \pm 12.21$ & $-9.13 \pm-9.30$ & $-7.93 \pm 4.74$ & $-1.71 \pm 3.50$ & $-3.27 \pm 1.44$ & $-0.41 \pm 0.2$ & $0.34 \pm 0.31$ \\
\hline Tree & 16.09 & 13.28 & 4.52 & 3.16 & 2.38 & 0.27 & 0.94 \\
\hline
\end{tabular}

\footnotetext{
a Standard deviation.
} 
pole trees would present a longer xylogenesis duration (Rossi et al., 2008; Vieira et al., 2009), and that a longer duration would be reflected in wider tree-rings (Campelo et al., 2013). However, the trees considered as young trees in those studies were all older than 45 years. This is the first time that trees younger than 15 years old are used to study xylogenesis. From our results, sapling/pole trees presented an intensive growth strategy, corresponding to a short period of xylem production with high growth rates. By adopting this strategy, sapling/pole trees can maximize stem radial growth when resources are available, thus reducing the risk of exposure to adverse conditions. On the other hand, young trees have access to water resources and reserves that sapling/ pole trees do not and thus can prolong the growing season at the cost of risking facing unfavorable climatic conditions.

\subsection{Climatic influence on xylogenesis}

Tracheid production was different not only between groups of trees but also between years. Sapling/pole trees formed a significantly higher number of tracheids in 2016 than in 2015, whereas young trees presented a similar tracheid production in both years. The year 2015 was characterized by a dry winter and spring, providing less water to the shallow root system of sapling/pole trees. Maritime pine trees present a deep taproot with a well-developed secondary system, capable of accessing water resources not available for sapling/pole trees (Abad Viñas et al., 2016). Several studies have reported a negative effect of water availability on the tree-ring width of pines growing in the Mediterranean region (Campelo et al., 2007; Nabais et al., 2014; Vieira et al., 2009; Zalloni et al., 2016). By presenting a shallower root system sapling/pole trees could not access the deeper soil water reserves that are available for older trees, thus forming less tracheids in 2015 (the driest year). Several studies have reported a negative effect of water stress on the tree-ring width of pines growing in the Mediterranean region (Campelo et al., 2007; Nabais et al., 2014; Vieira et al., 2009; Zalloni et al., 2016). Another possible explanation for the lack of differences in tracheid production in young trees between years with different soil water availability might the carry over effect. It is well established that the previous-year climate conditions have an influence in the current year growth (Vaganov et al., 2009). Young trees might have reduced growth in 2016 due to the pronounced drought observed in the previous year. Maritime pine is an isohydric species, closing stomata in response to water stress (Jones, 1998; Loustau et al., 1996). By doing so, less carbon is available for growth and less carbohydrates are stored (McDowell, 2011; McDowell et al., 2008). A reduction in the carbon pool of these trees could also be responsible for the lack of response to the release in water availability registered in 2016. Our results illustrate the different strategies that a tree presents during its lifetime. Sapling/pole trees are quick to respond to environmental stimuli, presenting an intensive growth strategy, whereas older and mature trees present a more conservative growth strategy.

\subsection{Tracheid properties}

The limiting effect of water availability was observed not only on the total number of tracheids, but also on the early/latewood proportion and on the anatomical properties of the tracheids. In 2015, young trees presented a higher proportion of latewood tracheids than in 2016. In response to water stress the mechanical function of xylem is promoted by increased deposition of wall material and by increasing the number of latewood cells (Björklund et al., 2017). Regarding the anatomical properties of tracheids, the earlywood tracheids formed by sapling/pole trees in 2015 presented a narrower lumen diameter. Cell growth, and in particular the turgor-mediated enlargement phase, are the most sensitive plant processes to water stress (Hsiao and Acevedo, 1974; Kutschera and Niklas, 2013). Tracheids with smaller lumen area have lower water requirements during the enlargement phase, so, if less water is available it would be expected that the tracheids would present a narrower lumen area. Tracheid size also represents an important trade-off between hydraulic conductivity and vulnerability to cavitation (Sperry et al., 2006). The resistance of tracheids to cell implosion under negative water tension increases with cell-wall thickness (Björklund et al., 2017; Sperry et al., 2006). In response to a drier growing season, sapling/pole trees formed earlywood tracheids with a narrower lumen area, increasing water conduction safety.

Cell wall thickness in earlywood and latewood was approximately the same in both age classes and years. A constant amount of cell wall material along the tree-ring has been reported by Cuny et al. (2014) for conifers growing in France. Our results are also in agreement with an earlier study performed in this area, that found less inter-annual variability in cell-wall thickness than in lumen diameter (Carvalho et al., 2015). Young trees presented a thicker cell-wall than sapling/ pole trees which is in agreement with the longer duration of the cellwall thickening phase observed in those trees.

\section{Conclusions}

It is the first time that xylogenesis is studied in sapling/pole trees (10-15 years old). In this study we compared the xylogenesis of sapling/pole and young (50-55 years old) maritime pine trees growing in the west coast of Portugal under a Mediterranean climate. We observed that the onset of xylem differentiation was similar between groups of trees and years and that although xylogenesis lasted longer on young trees, sapling/pole trees formed more tracheids in both study years. Sapling/pole trees presented an intensive growth strategy, characterized by a shorter growing season with a higher rate of cell production. Comparing both years, young trees formed approximately the same amount of tracheids in both years, but sapling/pole trees formed less tracheids with smaller lumen area and a higher latewood proportion in 2015. The year 2015 was very dry, with below average precipitation in the winter before the growing season and in spring. Sapling/pole trees are thus more sensitive to current year water availability than young trees.

The climatic scenarios projected for the Mediterranean region predict an increase of temperature and an alteration of the precipitation regime. Extreme years, characterized by high temperatures and low precipitation will become more frequent. This study demonstrated that sapling/pole trees are more sensitive to a decrease in precipitation. Thus, it is expected that saplings/pole trees will decrease wood production under the projected climate scenarios for the Mediterranean region and ultimately affecting the species distribution.

\section{Acknowledgments}

This study was supported by the Fundação para a Ciência e a Tecnologia, Ministério da Educação e Ciência (FCT) co-financed by Compete, through the projects EXPL/AAG-GLO/1885/2013, UID/BIA/ 04004/2013, and PTDC/AAG-GLO/4784/2014. Filipe Campelo (SFRH/ BPD/111307/2015) and Joana Vieira (SFRH/BPD/105656/2015) were supported by postdoctoral research grants from FCT with funds from POPH (Portuguese Operational Human Potential Program), QREN Portugal (Portuguese National Strategic Reference Framework) and FSE (European Social Fund).

\section{Appendix A. Supplementary material}

Supplementary data associated with this article can be found, in the online version, at http://dx.doi.org/10.1016/j.foreco.2018.04.037.

\section{References}

Abad Viñas, R., Caudullo, G., Oliveira, S., de Rigo, D., 2016. Pinus pinaster in Europe: distribution, habitat, usage and threats, in: San-Miguel-Ayanz, J., de Rigo, D., Caudullo, G., Houston Durrant, T., Mauri, A. (Eds.), European Atlas of Forest Tree 
Species. European Comission, pp. 128-129. doi:10.2788/038466

Begum, S., Nakaba, S., Yamagishi, Y., Oribe, Y., Funada, R., 2013. Regulation of cambial activity in relation to environmental conditions: Understanding the role of temperature in wood formation of trees. Physiol. Plant. 147, 46-54. http://dx.doi.org/ 10.1111/j.1399-3054.2012.01663.x.

Beniston, M., Stephenson, D.B., Christensen, O.B., Ferro, C.A.T., Frei, C., Goyette, S. Halsnaes, K., Holt, T., Jylha, K., Koffi, B., Palutikof, J., Scholl, R., Semmler, T., Woth, K., 2007. Future extreme events in European climate: an exploration of regional climate model projections. Clim. Change 81, 71-95. http://dx.doi.org/10.1007/ s10584-006-9226-Z.

Björklund, J., Seftigen, K., Schweingruber, F., Fonti, P., von Arx, G., Bryukhanova, M.V., Cuny, H., Carrer, M., Castagneri, D., Frank, D.C., 2017. Cell size and wall dimensions drive distinct variability of earlywood and latewood density in Northern Hemisphere conifers. New Phytol. 216, 728-740. http://dx.doi.org/10.1111/nph.14639.

Campelo, F., Gutiérrez, E., Ribas, M., Sánchez-Salguero, R., Nabais, C., Camarero, J.J., 2018. The facultative bimodal growth pattern in Quercus ilex - A simple model to predict sub-seasonal and inter-annual growth. Dendrochronologia 49, 77-88. http:// dx.doi.org/10.1016/j.dendro.2018.03.001.

Campelo, F., Nabais, C., Freitas, H., Gutierrez, E., 2007. Climatic significance of tree-ring width and intra-annual density fluctuations in Pinus pinea from a dry Mediterranean area in Portugal. Ann. For. Sci. 64, 229-238. http://dx.doi.org/10.1051/forest.

Campelo, F., Vieira, J., Nabais, C., 2013. Tree-ring growth and intra-annual density fluctuations of Pinus pinaster responses to climate: Does size matter? Trees - Struct. Funct. 27, 763-772. http://dx.doi.org/10.1007/s00468-012-0831-3.

Carrer, M., Urbinati, C., 2004. Age-dependent tree-ring growth responses to climate in Larix decidua and Pinus cembra. Ecology 85, 730-740.

Carvalho, A., Nabais, C., Vieira, J., Rossi, S., Campelo, F., 2015. Plastic response of tracheids in Pinus pinaster in a water-limited environment: adjusting lumen size instead of wall thickness. PLoS One 10, 1-14. http://dx.doi.org/10.1371/journal.pone 0136305.

Cherubini, P., Gartner, B.L., Tognetti, R., Braker, O.U., Schoch, W., Innes, J.L., 2003. Identification, measurement and interpretation of tree rings in woody species from mediterranean climates. Biol. Rev. 78, 119-148.

Christensen, J.H., Hewitson, B., Busuioc, A., Chen, A., Gao, X., Held, I., Jones, R., Kolli, R. K., Kwon, W.-T., Laprise, R., Rueda, V.M., Mearns, L., Menéndez, C.G., Räisänen, J., Rinke, A., Sarr, A., Whetton, P., 2007. Regional Climate Projections, in: Solomon, S., D. Qin, M. Manning, Z. Chen, M. Marquis, K.B. Averyt, M.T. and H.L.M. (Ed.), Regional Climate Projections. In: Climate Change 2007: The Physical Science Basis. Contribution of Working Group I to the Fourth Assessment Report of the Intergovernmental Panel on Climate Change. Cambridge University Press, Cambridge, United Kingdom and New York, NY, USA, pp. 847-940.

Coumou, D., Rahmstorf, S., 2012. A decade of weather extremes. Nat. Clim. Chang. 2, 491-496. http://dx.doi.org/10.1038/nclimate1452.

Cuny, H., Rathgeber, C.B.K., Frank, D., Fonti, P., Fournier, M., 2014. Kinetics of tracheid development explain conifer tree-ring structure. New Phytol. 203, 1231-1241. http://dx.doi.org/10.1111/nph.12871.

Cuny, H., Rathgeber, C.B.K., Frank, D., Fonti, P., Mäkinen, H., Prislan, P., Rossi, S., del Castillo, E.M., Campelo, F., Vavrčík, H., Camarero, J.J., Bryukhanova, M., Jyske, T., Gričar, J., Gryc, V., de Luis, M., Vieira, J., Čufar, K., Kirdyanov, A.V., Oberhuber, W., Treml, V., Huang, J.-G., Li, X., Swidrak, I., Deslauriers, A., Liang, E., Nöjd, P., Gruber, A., Nabais, C., Morin, H., Krause, C., King, G., Fournier, M., 2015. Woody biomass production lags stem-girth increase by over one month in coniferous forests. Nat. Plants 1, 15160. http://dx.doi.org/10.1038/nplants.2015.160.

Denne, M., 1989. Definition of latewood according to Mork. Iawa Bull 10, 59-62. http:// dx.doi.org/10.1163/22941932-90001112.

Hsiao, T.C., Acevedo, E., 1974. Plant responses to water deficits, water-use efficiency, and drought resistance. Agric. Meteorol. 14, 59-84.

Ivković, M., Gapare, W., Wu, H., Espinoza, S., Rozenberg, P., 2013. Influence of cambial age and climate on ring width and wood density in Pinus radiata families. Ann. For. Sci. 70, 525-534. http://dx.doi.org/10.1007/s13595-013-0290-z.

Jones, H.G., 1998. Stomatal control of photosynthesis and transpiration. J Exp Bot 49, 387-398.

Kutschera, U., Niklas, K.J., 2013. Cell division and turgor-driven stem elongation in juvenile plants: a synthesis. Plant Sci. 207, 45-56. http://dx.doi.org/10.1016/j. plantsci.2013.02004.

Li, X., Liang, E., Gričar, J., Prislan, P., Rossi, S., Čufar, K., 2013. Age dependence of xylogenesis and its climatic sensitivity in Smith fir on the south-eastern Tibetan Plateau. Tree Physiol. 33, 48-56. http://dx.doi.org/10.1093/treephys/tps113.

Loustau, D., Berbigier, P., Roumagnac, P., Arruda-Pacheco, C., David, J.S.S., Ferreira M.I.I., Pereira, J.S., Tavares, R., Roumagnac, P., 1996. Transpiration of a 64-year-old maritime pine stand in Portugal. 1.Seasonal course of water flux through maritime pine. Oecologia 107, 33-42. http://dx.doi.org/10.1007/BF00582233.

Lupi, C., Morin, H., Deslauriers, A., Rossi, S., 2010. Xylem phenology and wood production: resolving the chicken-or-egg dilemma. Plant. Cell. Environ. 33, 1721-1730. http://dx.doi.org/10.1111/j.1365-3040.2010.02176.x.

Lupi, C., Rossi, S., Vieira, J., Morin, H., Deslauriers, A., Tognetti, R., 2014. Assessment of xylem phenology: a first attempt to verify its accuracy and precision. Tree Physiol. 34, 87-93. http://dx.doi.org/10.1093/treephys/tpt108.

Martínez-Vilalta, J., Vanderklein, D., Mencuccini, M., 2007. Tree height and age-related decline in growth in Scots pine (Pinus sylvestris L.). Oecologia 150, 529-544. http:// dx.doi.org/10.1007/s00442-006-0552-7.

McDowell, N., 2011. Mechanisms linking dought, hydraulics, carbon metabolism, and vegetation mortality. Plant Physiol. 155, 1051-1059. http://dx.doi.org/10.1104/pp. 110.170704.

McDowell, N., Licata, J., Bond, B.J., 2005. Environmental sensitivity of gas exchange in different-sized trees. Oecologia 145, 9-20. http://dx.doi.org/10.1007/s00442-0050104-6|ISSN 0029-8549.

McDowell, N., Pockman, W.T., Allen, C.D., Breshears, D.D., Cobb, N., Kolb, T., Plaut, J., Sperry, J.S., West, A., Williams, D.G., Yepez, E.A., 2008. Mechanisms of plant survival and mortality during drought: why do some plants survive while others succumb to drought? New Phytol. 178, 719-739. http://dx.doi.org/10.1111/j.14698137.2008.02436.x.

Nabais, C., Campelo, F., Vieira, J., Cherubini, P., 2014. Climatic signals of tree-ring width and intra-annual density fluctuations in Pinus pinaster and Pinus pinea along a latitudinal gradient in Portugal. Forestry 87, 598-605. http://dx.doi.org/10.1093/ forestry/cpu021.

Pinheiro, J., Bates, D., DebRoy, S., Sarkar, D., Team, R.C., 2016. nlme: Linear and Nonlinear Mixed Effects Models.

Rathgeber, C.B.K., Longuetaud, F., Mothe, F., Cuny, H., Le Moguédec, G., 2011. Phenology of wood formation: Data processing, analysis and visualisation using $\mathrm{R}$ (package CAVIAR). Dendrochronologia 29, 139-149. http://dx.doi.org/10.1016/j dendro.2011.01.004.

Rossi, S., Anfodillo, T., Menardi, R., 2006. Trephor: A new tool for sampling microcores from tree stems. Iawa J. 27, 89-97.

Rossi, S., Deslauriers, A., Anfodillo, T., Carrer, M., 2008. Age-dependent xylogenesis in timberline conifers. New Phytol. 177, 199-208. http://dx.doi.org/10.1111/j.14698137.2007.02235.x.

Rossi, S., Deslauriers, A., Morin, H., 2003. Application of the Gompertz equation for the study of xylem cell development. Dendrochronologia 21, 33-39.

Rossi, S., Girard, M.J., Morin, H., 2014. Lengthening of the duration of xylogenesis engenders disproportionate increases in xylem production. Glob. Chang. Biol. 20, 2261-2271. http://dx.doi.org/10.1111/gcb.12470.

Santos-del-Blanco, L., Climent, J., González-Martínez, S.C., Pannell, J.R., 2012. Genetic differentiation for size at first reproduction through male versus female functions in the widespread Mediterranean tree Pinus pinaster. Ann. Bot. 110, 1449-1460. http:// dx.doi.org/10.1093/aob/mcs210.

Sperry, J.S., Hacke, U.G., Pittermann, J., 2006. Size and function in conifer tracheids and angiosperm vessels. Am. J. Bot. 93, 1490-1500. http://dx.doi.org/10.3732/ajb.93. 10.1490.

Szeicz, J.M., MacDonald, G.M., 1994. Age-dependent tree-ring growth responses of subarctic white spruce to climate. Can. J. For. Res. 24, 120-132. http://dx.doi.org/10. 1139/94-017.

Vaganov, E.A., Schulze, E.D., Skomarkova, M.V., Knohl, A., Brand, W.A., Roscher, C., 2009. Intra-annual variability of anatomical structure and $\delta 13 \mathrm{C}$ values within tre rings of spruce and pine in alpine, temperate and boreal Europe. Oecologia 161 729-745. http://dx.doi.org/10.1007/s00442-009-1421-y.

Vieira, J., Campelo, F., Nabais, C., 2009. Age-dependent responses of tree-ring growth and intra-annual density fluctuations of Pinus pinaster to Mediterranean climate. Trees - Struct. Funct. 23, 257-265. http://dx.doi.org/10.1007/s00468-008-0273-0.

Vieira, J., Campelo, F., Rossi, S., Carvalho, A., Freitas, H., Nabais, C., 2015. Adjustment capacity of maritime pine cambial activity in drought-prone environments. PLoS One 10, 1-15. http://dx.doi.org/10.1371/journal.pone.0126223.

Vieira, J., Rossi, S., Campelo, F., Freitas, H., Nabais, C., 2014a. Xylogenesis of Pinus pinaster under a Mediterranean climate. Ann. For. Sci. 71, 71-80. http://dx.doi.org/10 1007/s13595-013-0341-5.

Vieira, J., Rossi, S., Campelo, F., Nabais, C., 2014b. Are neighboring trees in tune? Wood formation in Pinus pinaster. Eur. J. For. Res. 133, 41-50. http://dx.doi.org/10.1007/ s10342-013-0734-X.

Wang, X., Zhang, Y., McRae, D.J., 2009. Spatial and age-dependent tree-ring growth responses of Larix gmelinii to climate in northeastern China. Trees - Struct. Funct. 23, 875-885. http://dx.doi.org/10.1007/s00468-009-0329-9.

S.N. Wood Generalized additive models: an introduction with R 2006 CRC Press, Taylor \& Francis, New York Texts in Statistical Science doi: 10.1111/j.1541-0420.2007.00905 3.x

Yu, G.R., Liu, Y.B., Wang, X., Ma, K.P., 2008. Age-dependent tree-ring growth responses to climate in Qilian juniper (Sabina przewalskii Kom). Trees-Struct. Funct. 22, 197-204. http://dx.doi.org/10.1007/s00468-007-0170-y.

Zalloni, E., de Luis, M., Campelo, F., Novak, K., Micco, V. De, Filippo, A. Di, Vieira, J., Nabais, C., Rozas, V., Battipaglia, G., 2016. Climatic signals from intra-annual density fluctuations frequency in Mediterranean Pines at a regional scale. Front. Plant Sci. 7, 1-11. http://dx.doi.org/10.3389/fpls.2016.00579. 